\title{
Pengaruh Model Pembelajaran Predict, Observe, Explain terhadap Hasil Belajar Siswa Kelas XI IPA pada Materi Fluida Statis di SMA Negeri 6 Palu
}

\author{
Rahwan, Syamsu, dan Yusuf Kendek \\ rahwan.fisika@gmail.com \\ Program Studi Pendidikan Fisika FKIP Universitas Tadulako \\ Jl. Soekarno Hatta Km. 9 Kampus Bumi Tadulako Tondo Palu - Sulawesi Tengah
}

\begin{abstract}
Abstrak-Penelitian ini dilakukan dengan tujuan untuk mengetahui ada tidaknya pengaruh model pembelajaran Predict, Observe, Explain terhadap hasil belajar siswa kelas XI IPA pada materi fluida statis di SMAN 6 Palu. Jenis penelitian ini merupakan eksperimen kuasi dengan desain non randomized pretest-posttest control group. Populasi penelitian ini adalah seluruh siswa kelas XI SMA Negeri 6 Palu. Teknik Sampling yang digunakan dalam penelitian ini adalah Proposive Sampling dengan sampel penelitian adalah kelas XI IPA 1 sebagai kelopok eksperimen dan kelas XI IPA 2 sebagai kelompok kontrol. Instrumen hasil belajar fisika berupa tes pilihan ganda yang telah divalidasi. Tes hasil belajar fisika yang diperoleh menunjukkan bahwa skor rata-rata kelompok eksperimen 17,02 lebih tinggi dari pada kelompok kontrol yaitu 13,70. Uji hipotesis Uji-t (dua pihak), diperoleh $t_{\text {hitung }}=3,73$ dan $t_{0,975(48)}=2,01$ pada taraf nyata $a=0,05$. Ini berarti bahwa nilai $t_{\text {hitung }}$ berada diluar daerah penerimaan $\mathrm{H}_{0}$. Sehingga dapat disimpulkan bahwa ada pengaruh model pembelajaran POE terhadap hasil belajar siswa kelas XI IPA pada materi fluida statis SMA Negeri 6 Palu
\end{abstract}

Kata Kunci: predict, observe, and explain, hasil belajar

\section{PENDAHULUAN}

Pendidikan merupakan salah satu faktor penting dalam suatu bangsa, karena menjadi tolak ukur kemajuan bangsa tersebut. Pendidikan juga berpengaruh terhadap kemajuan suatu negara. Tujuan utama pendidikan yang diperlukan adalah mempersiapkan manusia dalam menjalani kehidupan secara bertanggung jawab. Harapan masyarakat terhadap peningkatan kualitas pendidikan di Indonesia semakin besar.

Pembelajaran IPA di sekolah seharusnya melibatkan aspek sikap, proses, produk, dan aplikasi, sehingga siswa dapat mengalami proses pembelajaran secara utuh, memahami fenomena alam melalui kegiatan pemecahan masalah, metode ilmiah, dan meniru kerja ilmuan dalam menemukan fakta baru. Kecenderungan pembelajaran fisika saat ini, siswa hanya mempelajari fisika sebagai produk, menghapalkan konsep, teori dan hukum, serta berorientasi pada hafalan. Akibatnya, sikap, proses, dan aplikasi tidak tersentuh dalam pembelajaran. Pengalaman belajar yang diperoleh di kelas tidak utuh dan tidak berorientasi tercapainya standar kompetensi dan kompetensi dasar. Pada pembelajaran ini suasana kelas cenderung teacher-centered, guru hanya menyampaikan fisika sebagai produk dan siswa menghapal informasi factual [1].
Beban kurikulum mata pelajaran fisika yang terlalu banyak membuat sebagian besar guru lebih memilih menyelesaikan materi dan mengabaikan pemahaman serta penguasaan siswa. Akan tetapi, perlu diingat bahwa proses pembelajaran dengan metode ceramah tersebut mengakibatkan aktivitas siswa dalam pembelajaran menjadi kurang. Kurangnya aktivitas siswa tidak menutup kemungkinan akan berdampak pada rendahnya hasil belajar siswa [2].

Rendahnya tingkat pemahaman siswa dan minat belajar siswa terhadap mata pelajaran fisika menjadi suatu alasan perlunya pembaruan dalam strategi pembelajaran dan cara penyampaian materi kepada siswa karena pada dasarnya minat siswa dalam belajar fisika berhubungan erat dengan cara guru dalam menyampaikan materi yang diajarkan kepada siswanya yang nantinya akan berdampak pada hasil belajar siswa. Banyak cara yang dapat dilakukan dalam menyampaikan materi pelajaran fisika yang akan membuat siswa merasa senang dan tertarik untuk belajar fisika [3].

Berkenaan dengan hal tersebut, dapat diatasi dengan cara guru mengubah strategi mengajar yang lama dengan strategi mengajar baru yang lebih memberdayakan siswa untuk lebih aktif dalam pembelajaran, sehingga mencapai hasil belajar yang lebih baik. Salah satu cara yang dapat digunakan yaitu dengan 
menerapkan model pembelajaran yang tepat. Salah satu model pembelajaran yang dapat digunakan yaitu model pembelajaran POE (Predict, Observation and Explain). Menurut pendapat Indrawati dan Setiawan (2009), model pembelajaran POE didasarkan atas teori pembelajaran konstrutivisme yang memberi kesempatan bagi siswa untuk mengemukakan pengetahuan awal mereka. Tugas guru dalam pembelajaran menggunakan model POE adalah membimbing siswa melaksanakan tiga tugas, yaitu Predict (memprediksi), Observe (mengamati), dan Explain (menjelaskan) dengan tujuan untutk menggali pemahaman mereka tentang materi yang diajarkan [4].

Kelebihan model pembelajaran POE adalah siswa tidak hanya diajak untuk mengamati objek pembelajaran saja tetapi siswa juga dituntut aktif mencari pengetahuan dan berpikir kritis. Siswa diajak untuk berpikir kritis dengan cara memprediksi kemungkinan apa yang akan mereka temui pada saat mereka mengamati objek pembelajaran dan mendiskusikan antara hasil prediksi dengan pengamatan yang telah mereka lakukan [5].

\section{METODE PENELITIAN}

Jenis penelitian ini adalah penelitian eksperimen semu atau quasi eksperiment dengan desain "non randomized pretestposttest control group design" seperti Tabel 1 [6].

\begin{tabular}{|c|c|c|c|}
\hline Kelompok & Pretest & Perlakuan & Posttest \\
\hline$A(K E)$ & 0 & $X$ & $\mathrm{O}^{\prime}$ \\
\hline$A(K K)$ & 0 & - & $\mathrm{O}^{\prime}$ \\
\hline
\end{tabular}

$X$ : Perlakuan untuk kelas eksperimen dengan menggunakan model Pembelajaran Predict, Observe, Explain (POE)

$\mathrm{O}_{1}$ : Tes awal untuk kelas eksperimen dan kelas kontrol

$\mathrm{O}_{2}$ : Tes akhir untuk kelas eksperimen dan kelas kontrol
}

Populasi penelitian ini adalah seluruh siswasiswi kelas XI IPA SMA Negeri 6 Palu yang terdaftar pada tahun ajaran 2016/2017 yang terdiri dari 3 kelas. Sampel dari penelitian ini adalah sebagian yang diambil dari populasi ditentukan dengan menggunakan teknik purposive sampling atau "penentuan sampel dengan pertimbangan tertentu". yaitu kelas XI IPA I yang terdiri dari 25 siswa sebagai kelas Eksperimen dan XI IPA II yang terdiri dari 25 siswa sebagai kelas control. Penentuan sampel diambil sesuai dengan rekomendari dari guru mata pelajaran.

\section{HASIL DAN PEMBAHASAN}

\section{A. Hasil Penelitian}

Dari hasil analisis butir soal dengan menggunakan empat kriteria yaitu validitas, tingkat kesukaran, daya pembeda dan reliabilitas tes diperoleh soal yang memenuhi syarat untuk digunakan sebagai tes hasil belajar berjumlah 22 soal dari 35 soal yang diujikan.

1. Deskripsi Skor Pretest

Deskripsi skor pretest kelas eksperimen dan kelas kontrol yang terdiri dari 25 siswa diperoleh rekapitulasi data sebagai berikut:

\begin{tabular}{|c|c|c|c|}
\hline \multirow[t]{2}{*}{ No } & \multirow{2}{*}{$\begin{array}{l}\text { Distribusi } \\
\text { Frekuensi }\end{array}$} & \multicolumn{2}{|c|}{ Pretest } \\
\hline & & Eksperimen & Kontrol \\
\hline 1 & Skor Tertinggi & 14 & 13 \\
\hline 2 & Skor Terendah & 3 & 3 \\
\hline 3 & Skor rata-rata & 7,98 & 7,90 \\
\hline 4 & Standar Deviasi & 3,33 & 3,37 \\
\hline
\end{tabular}

Berdasarkan Tabel 2 terlihat bahwa rata-rata skor pretest siswa kelas eksperimen lebih tinggi 0,08 dibanding kelas kontrol namun perbedaan tidak terlalu signifikan.

\section{Deskripsi Skor Posttes}

Deskripsi skor posttest kelas eksperimen dan kelas kontrol yang terdiri dari 25 siswa diperoleh rekapitulasi data sebagai berikut:

\begin{tabular}{cccc} 
TABEL 3 & DATA HASIL POSTTEST & \multicolumn{2}{c}{ Pretest } \\
\cline { 3 - 4 } No. & Distribusi & \multicolumn{2}{c}{ Eontrol } \\
\cline { 3 - 4 } & Frekuensi & 21 & 18 \\
2 & Skor Tertinggi & 11 & 8 \\
3 & Skor Terendah & 17,02 & 13,70 \\
4 & Skor rata-rata & 3,12 & 3,16 \\
\hline
\end{tabular}

Berdasarkan Tabel 3 terlihat bahwa rata-rata skor posttest siswa kelas eksperimen sebesar 17,02 sedangkan skor rata-rata yang diperoleh kelas control sebesar 13,70. Standar deviasi yang diperoleh kelas eksperimen sebesar 3,12 dan kelas kontrol sebesar 3,16.

\section{a. Uji Normalitas}

Uji normalitas terhadap kelas eksperimen dan kelas kontrol menggunakan uji Chi Kuadrat untuk mengetahui apakah populasi data berdistribusi normal atau tidak. Data yang akan diujikan adalah data hasil Pretest dan Posttest. Dalam penelitian ini, hasil uji normalitas yang diperoleh disajikan pada Tabel 4. 
TABEL 4 UJI NORMALITAS PRETEST DAN POSTTEST KELAS EKSPERIMEN DAN KELAS KONTROL

\begin{tabular}{ccccc}
\hline Uraian & \multicolumn{2}{c}{ Kelas Eksperimen } & \multicolumn{2}{c}{ Kelas Kontrol } \\
\cline { 2 - 5 } & Pretest & Posttest & Pretest & Posttest \\
\hline Jumlah & 25 & 25 & 25 & 25 \\
Siswa & & & & \\
$\chi_{\text {hitung }}^{2}$ & 4,14 & 5,01 & 4,67 & 3,15 \\
$\chi_{\text {tabel }}^{2}$ & 7,81 & 7,81 & 7,81 & 7,81 \\
\hline
\end{tabular}

Dari Tabel 4 terlihat bahwa nilai $\chi_{\text {hitung }}^{2}$ kelas eksperimen maupun kelas kontrol lebih kecil dari pada nilai $\chi_{\text {tabel }}^{2}$. Artinya, hasil ini menunjukkan bahwa data pretest kelas eksperimen maupun kelas kontrol terdistribusi normal.

\section{b. Uji Homogenitas}

Setelah kedua kelompok sampel penelitian dinyatakan berdistribusi normal, selanjutnya dicari nilai homogenitas. Uji homogenitas pada penelitian ini menggunakan uji $\mathrm{F}$ dengan taraf signifikansi $a=0,05$. Adapun hasil $u j i$ homogenitas pada kelas eksperimen dan kontrol dilihat pada Tabel 5;

TABEL 5 HASIL UJI HOMOGENITAS PRETEST DAN POSTTEST KELAS

\begin{tabular}{|c|c|c|c|c|}
\hline \multirow[b]{2}{*}{ Uraian } & \multicolumn{2}{|c|}{ Pretest } & \multicolumn{2}{|c|}{ Posttest } \\
\hline & $\begin{array}{c}\text { Eksperim } \\
\text { en }\end{array}$ & Kontrol & $\begin{array}{c}\text { Eksperime } \\
\mathrm{n}\end{array}$ & Kontrol \\
\hline $\begin{array}{c}\text { Nilai } \\
\text { Varians }\end{array}$ & 11,09 & 11,33 & 9,76 & 10 \\
\hline $\begin{array}{c}\text { Varians } \\
\text { Hitung } \\
\text { Nilai }\end{array}$ & \multicolumn{2}{|c|}{1,02} & \multicolumn{2}{|c|}{1,02} \\
\hline $\begin{array}{c}F_{\text {tabel }}(a= \\
0,05)\end{array}$ & \multicolumn{2}{|c|}{3,13} & \multicolumn{2}{|c|}{3,13} \\
\hline
\end{tabular}

Homogen

Homogen

Berdasarkan hasil output uji homogenitas pada Tabel 5 dengan taraf signifikan $(a=0,05)$, dari data tersebut terlihat bahwa $F_{\text {hitung }}$ lebih kecil dari $\mathrm{F}_{\text {tabel }}$, maka berdasarkan kriteria pengabilan keputusan dapat disimpulkan bahwa tidak terdapat perbedaan varians antara kelas eksperimen dan kelas kontrol atau dengan kata lain varians antara kelas eksperimen dan kelas kontrol adalah sama atau homogen.

\section{c. Uji Hipotesis (Uji-t)}

Berdasarkan uji prasyarat analisis statistik diperoleh bahwa data pretest dan Posttest terdistribusi normal dan homogen, sehingga pengujian hipotesis yang digunakan adalah ujit (uji dua pihak).

TABEL 6 HASIL UJI HIPOTESIS (PRETEST) KELAS EKSPERIMEN DAN KELAS

\begin{tabular}{ccccc} 
KONTROL & & & & \\
\hline Kelas & $\bar{X}$ & $t_{\text {hitung }}$ & $\begin{array}{l}t_{\text {tabel }} \\
=0,05)\end{array}$ & Keputusan \\
\hline $\begin{array}{c}\text { Eksperimen } \\
\text { Kontrol }\end{array}$ & $\begin{array}{l}7,98 \\
7,90\end{array}$ & 0,08 & 2,01 & $\begin{array}{c}\mathrm{H}_{0} \\
\text { diterima }\end{array}$ \\
\hline
\end{tabular}

Berdasarkan data Tabel 6 dan ktiteria pengujian dimana $\mathrm{H}_{0}$ diterima jika $t_{\left(1 \frac{1}{2} a\right)}<t<$ $t_{\left(1 \frac{1}{2} a\right)}$ pada taraf signifikan 0,05 dan $\mathrm{dk} 48$, diperoleh $t_{0,975(48)}=2,01$ dan $t_{\text {hitung }}=0,08$. Hal ini menunjukan bahwa nilai $t_{\text {hitung }}$ berada pada daerah penerimaan $\mathrm{H}_{0}$. Sehingga dapat dikatakan bahwa tidak ada pengaruh model pembelajaran POE terhadap hasil belajar fisika siswa

TABEL 7 HASIL UJI HIPOTESIS (POSTTEST) KELAS EKSPERIMEN DAN

\begin{tabular}{|c|c|c|c|c|}
\hline Kelas & $\bar{X}$ & $t_{\text {hitung }}$ & $\begin{array}{l}t_{\text {tabel }} \\
(a \\
=0,05)\end{array}$ & $\begin{array}{c}\text { Keputusa } \\
\mathrm{n}\end{array}$ \\
\hline $\begin{array}{c}\text { Eksperimen } \\
\text { Kontrol }\end{array}$ & $\begin{array}{l}17,02 \\
13,70\end{array}$ & 3,73 & 2,01 & $\begin{array}{c}\mathrm{H}_{1} \\
\text { diterima }\end{array}$ \\
\hline
\end{tabular}

Berdasarkan data Tabel 7 diketahui $t_{\text {hitung }} \geq$ $t_{\text {tabel }}$ atau $3,73 \geq 2,01$. Hal ini menunjukan bahwa nilai $t_{\text {hitung }}$ berada pada daerah penolakan $\mathrm{H}_{0}$, dengan demikian maka $\mathrm{H}_{1}$ diterima. Sehingga dapat disimpulkan bahwa Ada pengaruh model pembelajaran POE terhadap hasil belajar fisika siswa. Dengan kata lain, nilai hasil belajar kelas eksperimen lebih tinggi dibandingkan dengan kelas control.

\section{B. Pembahasan}

Berdasarkan analisis kuantitatif, kemampuan awal siswa dengan memberikan tes awal diketahui skor rata-rata untuk kelas eksperimen 7,98 dan untuk kelas kontrol 7,90. Hal ini menunjukkan kemampuan akademik siswa sebelum diberikan perlakuan dianggap sama sebelum diberi perlakuan. Dan setelah diberi perlakuan, kemampuan akhir siswa dengan memberikan posttest diketahui skor rata-rata untuk kelas eksperimen sebesar 17,02 dan untuk kelas kontrol 13,70. Hasil ini menunjukkan adanya perbedaan skor antara dua kelas, dimana skor rata-tara kelas eksperimen lebih tinggi dibandingkan kelas kontrol, hasil pemberian posttest ini didukung oleh hasil analisis uji hipotesis (Uji-t) dua pihak. Dimana dari perhitungan diperoleh nilai $t_{\text {hitung }}=3,73$ dan $t_{\text {tabel }}=2,01$. Berdasarkan hasil tersebut diketahui nilai $t_{\text {hitung }} \geq t_{\text {tabel }}$ atau 3,73 $\geq 2,01$, yang artinya hipotesis $\mathrm{H}_{1}$ diterima. Dengan kata lain ada pengaruh hasil belajar fisika siswa yang menggunakan model pembelajaran POE dengan hasil belajar fisika siswa yang menggunakan model pembelajaran konvensional pada siswa SMA Negeri 6 Palu

Pelaksanaan penelitian pada kegiatan inti di kelas eksperimen dilakukan oleh peneliti dengan fase-fase sebagai berikut, menjelaskan mengenai teknik pelaksanaan model pembelajaran POE. Selanjutnya, peneliti 
meminta siswa untuk membentuk kelompok yang terdiri dari 4-5 siswa di setiap kelompok. Peneliti membagikan LKS kepada masingmasing siswa kemudian menginstruksikan kepada siswa untuk membuat prediksi sebanyak mungkin dari masalah yang diberikan dengan membaca referensi mengenai materi Fluida statis. Setelah siswa selesai membuat prediksi, selanjutnya peneliti menginstruksikan siswa untuk melakukan observasi terhadap masalah yang diberikan sesuai dengan petunjuk yang terdapat pada LKS. Pada tahap ini siswa diminta untuk melakukan percobaan dengan tujuan untuk menguji kebenaran prediksi yang mereka sampaikan.

Siswa mengamati apa yang terjadi pada percobaan. Setelah itu, menginstruksikan kepada siswa untuk membuat penjelasan terutama tentang kesesuaian dan ketidaksesuaian antara dugaan dengan hasil eksperimen dari tahap observasi yang telah dilakukan lalu mempresentasikan hasil yang diperoleh kepada siswa lain. Pada tahap ini, terdapat beberapa kelompok yang memiliki ketidaksesuain antara prediksi dan hasil observasi sehingga terjadi diskusi antara kelompok satu dengan kelompok lainnya yang membuat siswa memperoleh penjelasan tentang kebenaran dan mengalami perubahan konsep dari konsep yang tidak benar menjadi benar. Sementara itu, kelompok yang memiliki kesesuaian antara prediksi dan hasil observasi membuat siswa semakin yakin akan konsepnya. Maka, melalui tahap ini siswa dapat belajar dari kesalahan sehingga tidak mudah melupakannya. Kemudian, peneliti meluruskan penjelasan dari siswa dan memberikan penguatan kepada siswa.

Proses pembelajaran yang berlangsung di kelas kontrol menggunakan model pembelajaran konvensional yang sering digunakan di SMA Negeri 6 Palu. Pelaksanaan fase-fase pembelajaran pada kegiatan inti di kelas kontrol dimulai dengan menjelaskan secara keseluruhan mengenai materi fluida statis kepada siswa kemudian memberikan kepada siswa untuk bertanya mengenai penjelasan yang diberikan ataupun peneliti bertanya kepada siswa dan memberikan kesempatan kepada siswa untuk menjawab pertanyaan yang diberikan. Selanjutnya, peneliti memberikan contoh soal mengeni materi pembahasan kepada siswa lalu meminta siswa untuk memerhatikan contoh soal agar siswa dapat mengerjakan latihan soal yang guru berikan selanjutnya. Setelah itu, peneliti meminta siswa untuk maju didepan kelas untuk mengerjakan soal latihan agar temanteman siswa yang lain memerhatikan pekerjaan temannya mereka diperbolehkan untuk menanggapi jawaban pekerjaan temannya, kemudian guru menyimpulkan dan eluruskan jawaban siswa. Sebelum kelas ditutup guru memberikan kesempatan kembali pada siswa untuk bertanya jika masi ada penjelasan yang kurang dipahami mengenai materi secara keseluruhan.

Berdasarkan fase-fase tersebut, menunjukkan bahwa model pembelajaran POE lebih efektif digunakan dibandingkan model pembelajaran konvensional dimana model pembelajaran konvensional lebih berpusat kepada guru sementara pada model pembelajaran POE siswa dapat lebih aktif untuk mencari pengetahuan dan konsep fisika selain itu siswa juga mempunyai banyak kesempatan untuk mengolah informasi yang mereka peroleh.

Setelah dilakukan pembuktian antara dua variabel dengan menggunakan uji-t dapat diketahui bahwa pengujian hipotesis penelitian ini terdapat pengaruh yang cukup signifikan antara kelas yang menggunakan model pembelajaran POE dengan kelas yang menggunakan model pembelajaran konvensional. Model pembelajaran POE ini dapat berpengaruh terhadap hasil belajar siswa dikarenakan pada model pembelajaran ini proses pembelajarannya tidak berlangsung satu arah sehingga siswa tidak hanya terfokus oleh penjelasan guru. Siswa akan terbiasa untuk belajar mandiri serta siswa dapat merasa tertantang untuk membuktikan prediksinya melalui suatu eksperimen sehingga membuat suasana kelas lebih menyenangkan. Hal ini sesuai dengan penelitian yang pernah dilakukan oleh Suleman, yang menyimpulkan bahwa penggunaan strategi pembelajaran dengan teknik Predict-Observe-Explaint ini ketika diterapkan di kelas yang diuji yakni pada kelas eksperimen membuat siswa lebih aktif dan dari hasil skor Posttest lebih tinggi [7].

Pembelajaran dengan menerapkan model pembelajaran POE dapat membantu siswa untuk memahami konsep dengan baik serta mampu mengingat materi lebih lama khususnya pada mata pelajaran fisika. Hal ini dikarenakan model pembelajaran POE melibatkan siswa dalam meramalkan suatu fenomena, melakukan observasi melalui demonstrasi atau eksperimen, dan akhirnya menjelaskan hasil demonstrasi dan ramalan mereka sebelumnya. Dengan cara mengamati secara langsung siswa akan memiliki 
kesempatan untuk membandingkan antara teori (dugaan) dengan kenyataan. Dengan demikian siswa akan lebih meyakini kebenaran materi pembelajaran dan mengingatnya dalam jangka waktu yang lama.

\section{IV.KESIMPULAN DAN SARAN}

\section{A. Kesimpulan}

Berdasarkan hasil analisis data yang dilakukan, maka dapat disimpulkan bahwa ada pengaruh model pembelajaran POE terhadap hasil belajar fisika siswa. Hal ini dilihat dari hasil analisis data statistik menggunakan Uji-t dua pihak sampel independent diperoleh nilai $t_{\text {hitung }}>t_{\text {tabel }}$ atau $3,73>2,01$ pada taraf signifikan $\alpha=0,05$ dan derajat kebebasan, $\mathrm{dk}$ $=48$ sehingga hipotesis dapat diterima.

B. Saran

Dengan demikian, penulis mengajukan saran yang dapat dijadikan pertimbangan, yaitu guru hendaknya dapat menggunakan model pembelajaran Predic, Observe, Explan (POE) sebagai alternatif dalam proses belajar mengajar, karena model pembelajaran Predic, Observe, Explan (POE) berpengaruh positif dalam meningkatkan hasil belajar siswa.

\section{DAFTAR PUSTAKA}

[1] W. Widayanti. Peningkatan Aktivitas Belajar dan Hasil Belajar Siswa dengan Metode Problem Based Learning Pada siswa Kelas VIIA MTs Negeri Donomulyo Kulon Progo Tahun Ajaran 2012/2013. Universitas Ahmad Dahlan. Yokyakarta. 2013.

[2] U. Rochimah dan W. Akhdinirwanto Penerapan Field Study untuk Peningkatan Aktivitas dan Prestasi Belajar Fisika Kelas XI IPA Madrasah Aliah An Nawawi Berjan Purworejo. Dalam Prosiding Seminar Nasional Penelitian, Pendidikan dan Penelitian MIPA. Universitas Negeri Yogyakarta. 2011.

[3] A. Sari. Meningkatkan Pemahaman Konsep Fisika Melalui Model Pembelajaran Inkuiri dengan Menggunakan Metode Pictorial Riddle Pada Siswa Kelas X SMA Negeri 3 Palu. Skripsi Sarjana pada Program Studi Pendidikan Fisika FKIP UNTAD Palu: Tidak Diterbitkan. 2012.

[4] Indrawati. dan W. Setiawan. Pembelajaran Aktif, Kreatif, Efektif, dan Menyenangkan Untuk Guru SD. Bandung: Pusat Pengembangan dan Pemberdayaan Pendidik dan Tenaga Kependidikan Ilmu Pengetahuan Alam (PPPTK IPA). 2009.

[5] N. A. Y. Firdos, E. Rudyatmi, dan L. Herlina. "Pengaruh Model Pembelajaran Predict, Observe, Explain Dengan Bantuan Media Foto Pada Materi Struktur dan Fungsi Jaringan Tumbuhan". Unnes.J.Biol.Educ. 2 (2). 2013.

[6] H. Saldi. "Pengaruh Pendekatan Saintifik Melalui Model Pembelajaran Kooperatif Tipe Jigsaw di Kelas X SMA Negeri 9 Palu Pada Materi Stoikiometri. Skripsi Sarjana Pada Program Studi Pendidikan Kimia FKIP UNTAD Palu. 2015.

[7] F. Suleman. "Pengaruh Strategi Pembelajaran Dengan Teknik POE Terhadap Hasil Belajar Konsep Larutan Elektrolit dan Nonelektrolit Siswa di Kelas SMA Negeri 1 Nabila". Jurnal Penelitian. Jurusan Pendidikan Kimia Fakultas Matematika dan IPA. Universitas Negeri Gorontalo.2015. 
Jurnal Pendidikan Fisika Tadulako Online (JPFT)

Vol. 7 No. 1 p-ISSN 2338-3240, e-ISSN 2580-5924 